\title{
Makna Tradisi Ruwatan Adat Jawa Bagi Anak Perempuan Tunggal Sebelum Melakukan Pernikahan di Desa Pulungdowo Kecamatan Tumpang Kabupaten Malang
}

\author{
Dinna Eka Graha Lestari, S.Pd., M.Si \\ IKIP Budi Utomo Malang \\ dynna_lestari@yahoo.com
}

\begin{abstract}
Javanese traditional ruwatan tradition for single daughters before marriage in Pulungdowo Village, Tumpang District, Malang Regency. This research is motivated by the existence of marriage rules on single daughters. Where is the only child when going to marriage must do ruwatan first. The purpose of ruwatan is to eliminate the danger that will befall an only child and so that it does not become food from Batarakala. This ruwatan tradition is mandatory, meaning that if it does not carry out ruwatan then the only child is believed to get bad luck or distress.
\end{abstract}

Keywords: tradition; javanese; ruwatan

\section{PENDAHULUAN}

Perkawinan merupakan sebuah penyatuan dua jiwa, menjadi sebuah keluarga melalui akad perjanjian yang diatur oleh agama.Perkawinan merupakan salah satu bentuk ibadah. Tujuan perkawinan bukan saja untuk menyalurkan kebutuhan biologis, tetapi juga untuk menyambung keturunan dalam rumah tangga yang penuh kedamaian dan cinta kasih (M.Hariwijaya,2005:1). Aturan perkawinan yang diatur dalam masyarakat umumnya terkadang tidak sama dengan aturan yang berlaku di masyarakat Jawa, karena hal tersebut tidak lepas dari pengaruh dan peranan adat istiadat dalam masyarakat yang berlaku dimana masyarakat itu berada. Adat masyarakat memang dominan dan mempunyai daya ikat yang kuat karena mempunyai pengaruh yang besar dalam tingkah laku dan perbuatan masyarakat itu sendiri, maka dari itu adat akan menjadi sebuah peraturan yang memang harus dipatuhi. Sering terjadi perbedaan dalam perkawinan dengan sistem adat yang berlaku pada suatu daerah baik itu tradisi yang sudah mengakar menjadi sebuah hukum adat maupun yang sifatnya hanya sebatas kebiasaan saja.tradisi merupakan salah satu fenomena kebudayaan karena tradisi merupakan praktek kebudayaan dari suatu komunitas. Praktek dalam kebudayaan dapat memperlihatkan makna dari nilai kebudayaan, dimana nilai-nilai kebudayaan merupakan tujuan dari manusia untuk memenuhi kebutuhan dasarnya (Adeney, 2000:159). Tradisi merupakan suatu tindakan yang berulang-ulang kali terjadi yang dilakukan dan diwariskan secara turun-temurun salah satunya Tradisi Ruwatan sebagai salah satu warisan tradisional Jawa sampai sekarang masih dilestarikan. Ruwatan merupakan proses penyucian dalam mengatasi atau menghindarkan sesuatu kesulitan batin dengan dengan jalan mengadakan pertunjukan wayang kulit dengan mengambil cerita tertentu dalam pewayangan yaitu cerita lakon dari Murwakala (Soetarto, 1980:77). 
Jawa yang merupakan salah satu suku terbesar di Indonesia yang memiliki keanekaragaman budaya. Selain kebudayaan yang bersifat mistis, masyarakat Jawa juga mengenal adanya kebudayaan-kebudayaan yang dilestarikan sampai saat ini dan juga tradisi-tradisi kebudayaan. Masyarakat Jawa yang kental dengan kepercayaan mistis atau sering disebut juga kepercayaan dalam dunia spiritual (Rohani). Masyarakat Jawa juga memiliki berbagai teori yang menjadi dasar dilakukannya sebuah ritual. Upacara atau ritual yang dilakukan untuk menghindarkan diri dari dampak yang ditimbulkan akibat kesalahan manusia dalam masyarakat Jawa disebut Ruwatan. Upacara Ruwatan, dalam adat istiadat Jawa telah hidup beberapa puluh tahun yang lalu sampai sekarang masih dilakukan dan dilestarikan oleh orang-orang yang mempercayainya. Upacara Ruwatan sangat erat hubungannya dengan cerita pewayangan lakon wayang Murwakala. Biasanya kisah Murwakala tidak dapat dipisahkan dengan kelahiran seseorang yang melakukan kesalahan dalam aktivitas kehidupannya. Kedudukan orang yang seperti itu dalam keadaan bahaya karena jatuh dalam malapetaka terkena kutukan Batara Kala, sehingga disebut sebagai wong sukerta. Sukerta yang dimaksud adalah sosok anak yang mendapat kesialan karena terdapat satu atau lebih alasan yang menjadikannya sebagai mangsa dari Batarakala.Dalam bahasa Jawa, sukerta artinya yang hendaknya harus dibersihkan

\section{METODE PENELITIAN}

Penelitian ini menggunakan metode penelitian kualitatif deskriptif, yang menyatakan bahwa deskriptif adalah penelitian yang menyajikan data-data yang diteliti dengan menggambarkan gejala tertentu (Sugiyono,2010:3).
kotorannya.Cara membersihkan kotoran itulah yang kemudian disebut upacara ruwatan (Rusdi, 2012:2).Untuk menghilangkan kutukan Batara Kala itu harus melalui upacara yang disebut upacara Ruwatan.ruwatan merupakan upacara atau ritual yang dilakukan untuk menghindarkan diri dari dampak yang buruk yang ditimbulkan akibat kesalahan manusia. Dalam masyarakat Jawa yang di kenal dengan kepercayaan mistis atau sering disebut juga kepercayaan dalam dunia Spiritual (Rohani), masyarakat Jawa memiliki beragam teori yang menjadi dasar dilakukannya sebuah ritual yaitu yang disebut dengan Ruwatan (Ragil Pamungkas, 2008:3).Maksud dari tradisi ruwatan adalah untuk meminta dengan sepenuh hati agar anak tunggal terlepas dari malapetaka dan memperoleh rahayu atau keselamatan.Tradisi ruwatan sampai sekarang masih dilakukan dan masih menjadi tradisi karena merasa belum melaksanakan tradisi para leluhurnya, khawatirnya kalau terjadi hal-hal yang tidak diinginkan karena musibah yang berturut-turut menimpa walaupun secara religius telah menjalankan semua syariat dalam agamanya.Tradisi ruwatan anak tunggal baik laki-laki maupun perempuan sampai saat ini masih dilestarikan dan dilaksanakan secara turun-temurun oleh masyarakat.Hal tersebut dikarenakan sebagian besar masyarakat masih menganggap bahwa tradisi ruwatan merupakan kegiatan yang dianggap sakral.

Sehingga maksud dari penelitian ini yaitu menggambarkan, menguraikan realita yang menjadi adat di sebuah masyarakat dalam hal ini adalah tradisi Ruwatan. 


\section{HASIL DAN PEMBAHASAN}

\section{A. Sejarah Asal Mula Tradisi Ruwatan Adat Jawa}

Ruwatan merupakan sebagai salah satu warisan upacara tradisional masyarakat Jawa yang sampai sekarang masih dilestarikan.Dilestarikannya upacara ini karena keberadaannya memang dianggap masih bermanfaat bagi masyarajat sekitar.Lepas dari itu, Ruwatan bermula berkembang di dalam suatu cerita Jawa kuno yang pada pokoknya memuat masalah penyucian diri.Penyucian ini menyangkut pembebasan yang terkena kutukan atau tidak suci.Ruwatan ini dilakukan untuk pembebasan dari kesialan atau marabahaya.Ruwatan sering diartikan sebagai upaya untuk mengatasi atau menghindarkan diri dari sesuatu kesulitan yang mungkin akan diterima seseorang di dalam menjalani kehidupan. Ruwatan biasanya selalu diikuti dengan pertunjukan wayang kulit yang mengambil lakon tertentu (misalnya lakon Murwakala).Munculnya ruwatan juga disebabkan oleh adanya keyakinan bahwa manusia yang dianggap membawa sial dalam keberadaannya, sehingga perlu ditempatkan atau dikembalikan ke dalam kehidupannya yang lebih tentram dan sejahtera.Dalam masyarakat Jawa orang membawa kesialan disebut orang sukerta. Dalam keyakinan Jawa wong sukerta ini kalau tidak di ruwat akan menjadi makanan Batarakala.

Asal mula ruwatan anak tunggal (ontang-anting) yaitu dari sebuah cerita yang diambil dari pewayangan dengan lakon Murwakala. Cerita ini berawal dari pasangan antara Batara Guru dan Dewi Uma yng menandang asmara di atas angkasa. Perihal tentang sejarah asal mula ruwatan berawal dari birahi atau nafsu yang sangat besar dari Batara
Guru terhadap Dewi Uma.Waktu itu mereka mengelilingi pulau Jawa dengan menaiki punggung lembu dan terbang diangkasa.Setelah mereka mengelilingi pulau Jawa lalu terbang diatas samudera.Pada saat itu waktu matahari terbenam yaitu waktu senja dan ketika sinar matahari menyinari samudera, tertimbullah suatu pemandangan yang indah di lautan yang membiru penuh keindahan. Batara Guru kemudian memandang keindahan samudera itu, ketika memandangnya timbullah rasa dihatinya dengan bangkitnya asmara dengan Dewi Uma untuk melakukan hubungan intim.Sejak dari itulah bangkit sebuah rasa untuk berkeinginan berhubungan intim dengan Dewi Uma, tetapi Dewi Uma sama sekali tidak menanggapi keinginan dari Batara Guru sebab rasa dihatinya Dewi Uma masih jauh dari kata berhubungan intim. Namun Batara Guru berkeinginan keras untuk bisa berhubungan asmara dengan Dewi Uma, karena merasa telah ditolak keinginannya untuk bersenggama akhirnya Batara Guru memegang erat Dewi Uma kemudian dengan memaksa Dewi Uma. Karena kemarahannya akhirnya Dewi Uma dengan tidak sadar mengucapkan sebuah kata-kata yang mengatakan bahwa sifat kasar dari Batara Guru seperti raksasa yang bertaring, yang berbuat sesuatu disembarang tempat yaitu diatas punggung lembu yang dinaiki. Batara Guru tidak menghiraukan perkataan dari Dewi Uma karena tidak kuasa menahan gairah birahi atau nafsu untuk bersenggama kemudian timbul amarah dari Batara Guru. Kama (sperma) Batara Guru sudah terlanjur keluar dan tumpah di lautan, kemudian terdengarlah suara yang sangat menggelegar di lautan tersebut. Air laut bagaikan teraduk-aduk dan kemudian air laut itu menjadi panas bagaikan 
panasnya api. Batara Guru berkata bahwa yang tampak bersinar bagaikan matahari itu adalah kama (sperma) yang tidak bisa untuk dibinasakan karena sudah terlanjur terjadi. Mereka berusaha untuk membunuhnya namun kama (sperma) tersebut sangatlah kuat panasnya bagaikan api. Setelah beberapa lama kemudian kama (sperma) tersebut berwujud raksasa dan kemudian diberi nama Batarakala. Batarakala tersebut selalu meminta makanan tetapi makanannya selalu ditentukan yaitu seperti: anak tunggal (ontang-anting) yang tidak mempunyai saudara, anak lima laki-laki semua (pandawa lima) itu yang akan menjadi santapan atau makananan dari Batarakala. Maka dari itu untuk terhindar dari makanan Batarakala harus melakukan upacara ruwatan, lakon dari pewayangan yaitu Murwakala atau lakon ruwatan. Upacara ruwatan ini dianggap sebagai sarana pembebasan orang sukerta, yaitu anak yang sejak lahir dianggap membawa kesialan, penuh dosa, serta orang-orang yang akan diganggu sesama hidupnya. Dan sampai saat ini anak yang dianggap sukerta dipercayai akan dimangsa oleh Batarakala dan akan mendapatkan kesialan atau musibah.

Dari cerita pewayangan ini masyarakat Jawa meyakini bahwa tradisi ruwatan sangatlah penting bagi mereka yang mengharapkan keselamatan, khususnya bagi mereka yang dikaruniai hanya mempunyai satu anak atau anak tunggal.Agar anaknya tersebut selamat dan terhindar dari segala macam keburukan atau kesialan. Ruwatan yang diyakini oleh kebanyakan orang Jawa sebagai solusi agar jalma atau anak yang bersangkutan terhindar dari marabahaya adalah suatu upacara yang acaranya sebagai berikut:

a. Mengadakan pagelaran wayang. b. Sebagai pemandu pagelaran wayang yaitu Dalang.

c. Lakon yang dipentaskan adalah lakon khusus yaitu lakon Murwakala.

d. Menyajikan sesaji khusus.

e. Pada acara ruwatan, Dalang membaca mantra-mantra dengan iringan gamelan dan gending tertentu guna untuk tolak balak (mengusir Batarakala).

\section{B. Prosesi Tradisi Ruwatan Adat Jawa}

Cerita pewayangan juga menjelaskan beberapa syarat yang harus dipenuhi oleh anak tunggal yang diruwat agar anak tunggal tersebut tidak tertimpa musibah dan dijauhkan dari segala keburukan. Selesai acara ruwatan dan pagelaran wayang kulit, selanjutnya anak tunggal akan dimandikan dengan menggunakan macam-macam bunga setaman dan tujuh sumber air. Sebelum memandikan dalang tersebut membacakan ayat-ayat suci, do'a, dan juga mantara-mantra Jawa terlebih dahulu. Setelah dimandikan anak tunggal tersebut diharuskan membuang pakaian yang dipakainya sewaktu mandi. Membuangnya pun tidak sembarang tempat melainkan disungai yang aliran arus airnya yang cukup deras, dengan harapan semua kesialan yang telah atau bakal terjadi akan hilang dan menjauh. Setelah itu anak tunggal juga diharuskan untuk memakai pakaian-pakaian yang baru sebagai penganti, dengan harapan anak tunggal tersebut telah memulai lembaran baru dalam hidupnya yang penuh berkah dan kebahagiaan yang selalu menyertainya. Tata cara ruwatan:

a. Menyediakan ember (tempat air).

b. Mengisi air 7 sumber ke dalam ember yang sudah dipersiapkan. 
c. Kemudian ditaburi bunga setaman.

d. Membacakan ayat-ayat suci dan juga mantra-mantra, bagi yang muslim bersihkan diri dengan berwudhu.

e. Setelah itu airnya kemudian dimandikan ke anak tunggal yang diruwat.

f. Setelah selesai mandi kemudian diharuskan memakai pakaian yang bersih (disarankan memakai pakaian warna polos atau putih).

g. Setelah itu bunga yang terjatuh atau tercecer dilantai diambil kembali dan dikumpulkan disebuah wadah, begitupun sisa bunga yang ada didalam ember. Kemudian bunga tersebut di buang atau dihanyutkan ke sungai, dengan didasarkan pada "sengkala" (nasib buruk) harus di buang jauh-jauh dari dalam dirinya. Sedangkan sungai sebagai muara menuju ke laut bebas sebagai simbol dunia luas dan tak terbatas.

h. Setelah pembuangan bunga tersebut yang dipakai untuk ruwatan setelah itu acara potong rambut (tugel kuncung).

Selain itu, orang yang menyelenggarakan ruwatan ini biasanya harus melengkapi syaratsyarat yang diperlukan antara lain yaitu sajen. Sajen untuk upacara ruwatan terdiri dari:

1. Tuwuhan : mempunyai makna sebagai harapan akan kemakmuran. Kata tuwuh bisa dimaknai tumbuhdalam arti bahwa akan mulai tumbuh kehidupan baru atau rumah tangga baru.

2. Nasi golong : mempunyai makna agar mendapatkan rezeki yang bergantian.
3. Nasi kuning : mempunyai makna agar mendapatkan rezeki yang berlebih.

4. Nasi kabuli : mempunyai makna agar keinginan atau hajadnya segera terkabul.

5. Tumpeng : mempunyai makna untuk mensyukuri nikmat yang sudah diberikan oleh Allah.

6. Jenang abang : bermakna sebagai permohonan untuk mendapatkan keselamatan.

7. Jenang sengkolo : bermakna agar mendapatkan keselamatan atau agar dihindarkan dari kala atau marabahaya.

8. Jenang grendul : bermakna sebagai simbol keharmonisan hidup terutama dalam rumah tangga.

9. Apem : bermakna sebagai permohonan maaf atas kesalahan yang telah diperbuat.

10. Jajanan pasar : mempunyai makna sebagai harapan agar dipermudah dalam hal pangan.

11. Rujak (pisang klutuk) : mempunyai makna sebagai lambang penafsiran atas kebahagiaan seseorang terutama mempelai pengantin.

12. Padi : melambangkan kemakmuran dan bermakna sebagai harapan diberi cukup pangan.

13. Ndok Jawa (telur Jawa) : sebagai lambang kesucian seorang perempuan.

14. Gedang ayu : sebagai simbol bahwa manusia penghuni bumi sebagai bagian dari alam. 
15. Pisang raja : mempunyai makna sebagai agar dapat tercapai segala tujuan hidup dan cita-citanya.

16. Daun kluwih : mempunyai makna agar diberikan keluwihan (kelebihan) atau kecukupan.

17. Daun alang-alang : mempunyai makna agar dapat mengatasi segala halangan atau rintangan hidup.

18. Jambe : sebagai lambang pernikahan yaitu perpaduan dua orang menjadi satu dalam ikatan pernikahan.

19. Gambir : mempunyai makna sebagai

kesejahteraan untuk kehidupan yang akan dijalaninya.

20. Suruh : mempunyai makna sebagai tolak balak atau dihindarkan dari marabahaya.

21. Kembang setaman : sebagai harapan agar tujuannya segera tercapai.

22. Air tujuh sumber : mempunyai lambang bahwa dalam satu badan terdapat tujuh sumber air yaitu (1) mata, mengeluarkan air mata (2) hidung, mengeluarkan air ingus (3) bibir, mengeluarkan air ludah (4) kuping, mengeluarkan air kotoran (5) kemaluan, mengeluarkan air mani (6) anus, mengeluarkan air kotoran BAB (7) seluruh badan, mengeluarkan air keringat.

23. Duparatus (dupa) : sebagai lambang kesejahteraan dalam kehidupan yang dijalninya.
24. Ember : sebagai wadah atau alat yang digunakan untuk menaruh air dan bungan dalam prosesi ruwatan.

25. Empluk (lampu minyak) : mempunyai makna sebagai penerangan dalam menjalani kehidupan.

26. Kendhi : dimaknai bahwa air di dalam kendhi sebagai air alami dan suci atau disebut air kehidupan.

27. Siwur batok : alat tradisional yang digunakan untuk mengambil air ketika pelaksanaan siraman.

28. Kain lawon putih : mempunyai makna bahwa putih berarti suci dan diartikan sebagai sarana untuk mensucikan diri.

29. Kain batik : bermakna sebagai penyatuan dua roh manusia yang menghadirkan cinta.

30. Benang lawe : mempunyai makna bahwa pernikahan merupakan suatu ikatan yang lembut dan suci.

31. Kelapa : bermakna sebagai harapan untuk tetap memiliki niat dan tekad dalam menggapai sebuah keinginan.

32. Kinang dan rokok : melambangkan tentang kehidupan yang saling melengkapi atau saling berkaitan satu sama lain sehinggal bisa menjadi satu.

\section{Makna Tradisi Ruwatan Adat Jawa Bagi Anak Tunggal}

Makna dari ruwatan adalah meminta dengan sepenuh hati agar pelakunya lepas dari petaka dan memperoleh rahayu keselamatan. Tradisi ruwatan sampai sekarang masih 
dilakukan dan menjadi tradisi karena merasa belum nyaman kalau belum melaksanakan tradisi tersebut dan juga khawatir kalau terjadi hal-hal yang tidak diinginkan atau karena musibah yang bertubi-tubi menimpa walaupun secara sosial religius telah menjalankan semua syariat agamanya.Tradisi ruwatan anak tunggal hingga saat ini masih dilestarikan dan dilaksanakan secara turun-temurun oleh masyarakat setempat.Hal tersebut disebabkan oleh sebagian besar masyarakat masih menganggap bahwa tradisi ini merupakan kegiatan sakral.Maksud dari tradisi ruwatan ini adalah agar seseorang yang di ruwat dapat terbebas atau terlepas dari malapetaka.Seseorang yang dianggap mempunyai kesialan disebut sebagai sukerta, yang mana orang tersebut harus di ruwat. Tradisi kepercayaan masyarakat Jawa bahwa seseorang yang terkena sukerta akan mengalami kesialan di dalam hidupnya. Karena itu usaha yang dilakukan oleh masyarakat Jawa dengan mengadakan upacara ruwatan tersebut tak lain yaitu untuk melindungi manusia dari segala ancaman bahaya dari kehidupannya di dunia.

Tradisi ruwatan mempunyai makna filosofis dalam tahapan prosesi upacaranya yaitu sebagai berikut:

a. Prosesi siraman secara filosofis mengandung nilai untuk

\section{PENUTUP}

Tradisi ruwatan adat Jawa bagi anak perempuan tunggal di Desa Pulungdowo Kecamatan Tumpang Kabupaten Malang dilaksanakan ketika akan melakukan akad pernikahan. Tradisi ruwatan ini bersifat wajib artinya apabila tidak dilaksanakan maka anak perempuan tunggal tersebut akan mendapatkan kesialan, musibah, dan marabahaya yang akan mengancam terhadap keutuhan rumah tangganya. membersihkan badan agar manusia yang di ruwat dengan menggunakan air kembang setaman yang terdiri atas kembang kenanga, kembang melati, dan kembang mawar.

b. Sesaji dan selametan secara filosofis memiliki nilai agar orang yang di ruwat dalam keadaan selalu selamat.

c. Nilai filosofis yang terkandung dalam upacara penyerahan sarana adalah memberikan perlindungan terhadap orang yang tergolong sukerta.

d. Upacara potong rambut memiliki nilai filosofis yaitu bahwa segala yang kotor harus di potong dan di buang.

e. Nilai filosofis dalam tirakatan merupakan ungkapan rasa syukur dan ungkapan rasa terima kasih terhadap Tuhan Yang Maha Esa atas perlindungan dan anugerahnya.

f. Wayang juga membawa makna filosofis bagi kehidupan manusia. Manusia pada umumnya menginginkan kebaikan, maka kisah wayang itu banyak yang bisa sampai masuk ke hati. Makna wayang dalam ruwatan juga membawa makna kehidupan.

Tradisi ini dilakukan untuk menjaga agar keharmonisan rumah tangga, karena tradisi ruwatan ini dapat menghindarkan dari sengkala, marabahaya yang akan menimpanya serta agar tidak menjadi makanan dari Batarakala.Tata cara tradisi ruwatan pada anak perempuan tunggal dilaksanakan dengan menggunakan sarana kembang tujuh rupa, kain putih, jajanan pasar, serta berbagai macam 
sesajen dan alat yang dibutuhakan dalam ruwatan. Di mulai dari sambutan dalang atau kyai yaitu orang yang melaksanakan upacara, kemudian dilanjutkan dengan doa-doa yang dibacakan oleh dalang atau kyai dengan tujuan agar diberi keselamatan dan kelancaran dalam melaksanakan upacara tersebut.Kemudian yang dilanjutkan dengan prosesi ruwatan dimana anak perempuan tunggal (ontang-anting) dimandikan dengan air tujuh sumber dan kembang setaman. Selanjutnya dilanjutkan dengan pemotongan rambut (tugel kuncung) dengan harapan agar kesialan pada anak tunggal tersebut bisa hilang serta dijauhkan dari malapetaka yang akan menimpanya.

\section{DAFTAR PUSTAKA}

Adeney, Bernard. 2000. Etika Sosial Lintas Budaya. Yogyakarta: Pustaka Teologi dan Gandum Mas.

M.Hariwijaya, 2005. Perkawinan Adat Jawa. Yogyakarta: Hanggar.

Ragil Pamungkas. 2008. Tradisi Ruwatan. Yogyakarta: Narasi.

Rusdi, Sri Teddy. 2012. Ruwatan Sukerta. Jakarta: Yayasan Kertagama.

Soetarto. 1980. Tinjauan Asal Mula Wyang Purwa. Surakarta: PJKT.

Sugiyono. 2010. Metode Penelitian Pendidikan. Bandung: Alfabeta. 